\title{
KEBEBASAN BERAGAMA DAN DEMOKRATISASI DI INDONESIA
}

\begin{abstract}
M. Zainuddin
Fakultas Tarbiyah Universitas Islam Negeri Maulana Malik Ibrahim Malang. Jalan Gajayana No. 50 Malang. Telp: 08133417433. e_mail: aldin_uin@yahoo.com
\end{abstract}

\section{Abstract}

The objective of this research is to understand the religious freedom and the process of democratization in Indonesia. The result of this research shows that the religious freedom in Indonesia is regulated by the law. In this sense, religious freedom means freedom to choose and believe in certain religion, it does not mean that people have freedom to be atheism. In fact, the religious freedom in Indonesia has not run well since there is a religion banned by claiming it as a wrong and deviate religion. Furthermore, the violence by a religion to another religion is common in social life.

Key words: religious freedom, democratization

\section{Pendahuluan}

Kebebasan beragama di negara kita mengacu pada UUD 1945 pasal 29 ayat 2. Pasal ini menyatakan bahwa setiap warga diberi kemerdekaan atau kebebasan untuk memeluk agamanya masing-masing dan beribadat menurut agama dan kepercayaannya. 
Pasal 28 ayat 1 UUD 1945 perubahan kedua mengakui adanya hak setiap warga negara atas kebebasan beragama atau kepercayaan, demikian juga Pasal 28 ayat 1 UUD 1945 perubahan kedua, menjelaskan hak beragama dan berkepercayaan adalah Hak Asasi Manusia (HAM) yang tidak bisa dikurangi dan dibatasi dalam kondisi apapun. Bahkan Pasal 28 ayat 4 UUD 1945 perubahan kedua, mempertegas kewajiban negara terutama pemerintah untuk melindungi, memajukan, menegakkan dan memenuhi HAM. Kewajiban negara melindungi dan memenuhi hak atas kebebasan beragama dan kepercayaan mengandung pengertian, bahwa negara tidak mempunyai wewenang mencampuri urusan agama dan kepercayaan setiap warga negaranya. Sebaliknya, negara harus memberikan perlindungan terhadap setiap warga negaranya untuk melaksanakan ibadah keagamaan atau kepercayaan.

Hak Asasi Manusia merupakan suatu konsep etika politik modern dengan gagasan pokok penghargaan dan penghormatan terhadap manusia dan kemanusiaan. Gagasan ini mengandung konsekuensi tuntutan moral bagaimana seharusnya manusia memperlakukan sesamanya. Tuntutan moral tersebut sejatinya merupakan ajaran inti dari semua agama. Sebab, semua agama mengajarkan pentingnya penghargaan dan penghormatan terhadap manusia, tanpa ada pembedaan dan diskriminasi. Tuntutan moral itu diperlukan, terutama dalam rangka melindungi seseorang atau suatu kelompok yang lemah atau "dilemahkan" (al mustad'afin) dari tindakan semena-mena yang biasanya datang dari mereka yang kuat dan berkuasa.

Kesadaran akan pentingnya HAM dalam wacana global muncul bersamaan dengan kesadaran akan pentingnya menempatkan manusia sebagai titik sentral pembangunan (human centred development), yang harus dihormati tanpa membedakan ras, warna kulit, jenis kelamin, suku bangsa, bahasa, maupun agamanya.

Isu kebebasan beragama selain tercantum di dalam Deklarasi Universal Hak Asasi Manusia (DUHAM), ditemukan juga dalam berbagai dokumen historis tentang HAM, seperti dokumen International Bill of 
Rights (1966), Rights of Man France (1789), dan Bill of Rights of USA (1791). Pasal 2 DUHAM menyatakan:

"Setiap orang berhak atas semua hak dan kebebasan-kebebasan yang tercantum dalam Deklarasi ini tanpa perkecualian, seperti ras, warna kulit, jenis kelamin, bahasa, agama, politik atau pendapat yang berlainan, asal mula kebangsaan atau kemasyarakatan, hak milik, kelahiran, ataupun kedudukan lain.” (Musdah, 2005: 6).

Pemerintah dan DPR telah meratifikasi Kovenan Internasional tentang Hak Sipil dan Politik melalui UU No 12/2005. Pasal 18 ayat 1 Kovenan Internasional Sipil-Politik yang melindungi hak atas kebebasan berpikir, berkeyakinan dan beragama, termasuk hak untuk memeluk kepercayaan. Hak atas kebebasan beragama atau berkepercayaan tidak dapat dikurangi.

\section{Pluralisme dan Demokratisasi: Tantangan Bagi Agama-Agama}

Pluralisme memiliki beberapa perspektif, sosial, budaya maupun politik. Dalam perspektif sosial, pluralisme menangkal dominasi dan hegemoni kelompok atau aliran keagamaan, serta menegasikan pemusatan kekuatan sosial pada satu kelompok atau aliran. Sedangkan perspektif pluralisme budaya mencegah hilangnya satu aliran karena dilenyapkan oleh aliran keagamaan arus utama yang hegemonis, dan disisi lain menangkal arogansi aliran keagamaan arus utama yang seringkali tergoda atau secara historis-empiris melakukan pelecehan dan penindasan aliran atau agama lain. Sementara pluralisme politik dapat menjadi dasar bagi jaminan kebebasan untuk berkeyakinan dan berekspresi tanpa rasa takut akan ancaman kekerasan, karena adanya lembaga pengelola konflik kepentingan antaraliran keagamaan.

Pluralisme agama memiliki afinitas yang kuat bagi kehidupan demokrasi di masa depan, dan oleh karenanya dapat dijadikan dasar untuk memahami dan bersikap terhadap pluralitas agama dan keberadaan aliran keagamaa yang ada, serta menjadi landasan bagi pemberdayaan masyarakat sipil yang demokratis dan menjunjung tinggi martabat manusia (Billah, 2007: 8-9). 
Demokrasi sering diartikan sebagai penghargaan terhadap hak asasi manusia, partisipasi dalam pengambilan keputusan dan persamaan hak di depan hukum. Dari sini kemudian muncul idiom-idiom demokrasi, seperti egalite (persamaan), equality (keadilan), liberty (kebebasan), human right (hak asasi manusia), dan seterusnya.

Diskursus toleransi dan kebebasan beragama yang digagas oleh John Locke menegasikan adanya pemaksaan baik secara pribadi maupun kelompok dan bahkan lewat institusi untuk memeluk satu agama. Sejalan dengan Locke, keprihatinan Leibniz terhadap konflik KatolikKristen yang berujung perang selama kurang lebih 30 tahun (1618-1645) mendorongnya untuk berpikir secara plural. Dalam pandangan Leibniz, dunia ini terdiri dari bagian-bagian kecil atau substansi-substansi sederhana yang disebut monade, setiap monade mencerminkan dunia secara keseluruhan (universal). Oleh sebab itu, konflik atau perang berarti berlawanan dengan harmoni universal dunia (Haryatmoko, 1999: 99).

Suatu Negara yang memaksakan agama tertentu kepada rakyatnya akan membahayakan terhadap stabilitas politik. Hal ini dijelaskan pula oleh Spinoza, bahwa pemaksaan keyakinan kepada rakyat akan mengakibatkan pemberontakan sipil, politik dan agama. Oleh karena itu, menurutnya, negara harus mendukung toleransi dengan menjamin keamanan warga negara dalam mengeluarkan pendapatnya secara bebas, asalkan pendapat tersebut tidak berisi hasutan (Reese, 1999: 51).

Penindasan yang mengatasnamakan agama ditentang oleh John Locke, dia menambahkan bahwa toleransi agama harus diperluas kepada semua varian keyakinan dan ritual agama, namun dia mengeliminasi atheisme dalam perluasan toleransi tersebut.

Dalam konteks Indonesia, kebebasan beragama sebetulnya memiliki arti, bebas untuk memeluk agama yang diakui di Indonesia (Hindu, Budha, Islam Kristen, Katolik dan Konghucu). Bebas untuk berpindah dari agama satu ke agama lain, bebas untuk berpendapat dan mengekspresikan ajaran agama yang dipeluknya (bebas berijtihad). 
Abraham Kuyper membagi kebebasan beragama (religious freedom) menjadi tiga pengertian, religious pluralism, social pluralism dan confessional pluralism. Religious pluralism artinya, bahwa manusia berhak untuk memilih dan pindah agama tanpa campur tangan orang lain. Confessional pluralism artinya, manusia selain berhak memilih, juga berhak untuk menjalankan agama yang dipilihnya. Social pluralism artinya, agama berhak untuk menjadi hati nurani masyarakat (www. Islamlib.com).

Secara normatif-institusional, kebijakan toleransi beragama telah dirumuskan dalam perundang-undangan, namun dalam level praksis, rumusan yang ideal tersebut belum bisa diterjemahkan secara sempurna oleh sebagian masyarakat kita ke dalam kehidupan sehari-hari dengan indikasi masih adanya konflik dan gejolak di masyarakat yang mengusung isu-isu agama.

Bagaimana pengalaman demokrasi dalam konteks religious freedom di Indoensia? Secara empirik, kebebasan beragama di Indonesia belum berjalan dengan baik, terbukti masih ada agama yang dilarang karena dianggap "sesat". Masih terjadi tindak kekerasan oleh satu agama atau aliran terhadap agama atau aliran yang lain. Oleh karena itu, Negara atau pemerintah tidak berhak melarang agama apapun (yang sudah diakui) kecuali agama tersebut mengganggu ketertiban umum. Kasus pelarangan terhadap aliran agama yang dianggap sesat, seperti Ahmadiyah dan aliran keagamaan yang lain oleh pemerintah menunjukkan hal ini, demikian pula sekelompok umat yang melakukan tindak kekerasan dan pengerusakan tempat-tempat ibadah terhadap agama atau aliran lain juga merupakan bukti empirik akan adanya pelanggaran HAM tersebut. Dalam membuat kebijakan, pemerintah hendaknya memperhatikan aspirasi masyarakat yang berkembang, proaktif mendorong terwujudnya toleransi beragama dan memfasilitasi keinginan masyarakat untuk mendekatkan antara agama satu dengan agama lainnya atau antara aliran satu dengan aliran lainnya (baca: dialog antarumat beragama). 
Rumadi (Wahid Institute) mencatat 232 kasus pelanggaran HAM sepanjang Januari hingga November 2008. Kasus pertama dan tertinggi adalah, kekerasan berbasis agama sebanyak 55 kasus. Kedua, penyesatan agama sebanyak 50 kasus. Ketiga, hubungan antarumat beragama sebanyak 29 kasus. Sedangkan bentuk pelanggaran kebebasan beragama dan berkeyakinan terdapat 280 kasus. Kasus pertama dan tertinggi adalah, penyesatan agama sebanyak 43 kasus. Kedua, penyerangan fisik dan penganiayaan sebanyak 35 kasus. Ketiga, pembatasan kebebasan berekspresi sebanyak 27 kasus.

Sungguh hal tersebut adalah kasus-kasus yang fantastis, dan ini merupakan ironi bagi agama-agama sekaligus sebagai tantangan besar yang harus segera diatasi. Bahwa dalam konteks agama dan demokrasi, seharusnya agama menjadi penggerak demokrasi itu sendiri, sebab dipercaya, bahwa semua agama memiliki misi menegakkan nilai-nilai kemanusiaan universal, ini merupakan bagian dari idiom demokrasi. Sementara manusia beragama harus membawa misi tersebut dalam kehidupan bermasyarakat, berbangsa dan bernegara. Ada banyak ragam agama di dunia ini merupakan hal yang niscaya, itu adalah sebagai sunntullah. Namun yang harus dipahami, bahwa semua agama menyeru kepada kebaikan dan keharmonisan. Kebanyakan orang beragama demikian pula tokoh agamanya sering lupa, bahwa mereka hidup dalam negara Pancasila, yang sudah diatur oleh undang-undang dalam kehidupan berbangsa dan bernegara, sehingga tidak ada alasan untuk memaksa dan melakukan hegemoni terhadap orang lain atau agama dan kepercayaan lain. Begitu pula sebagian umat Islam juga tidak ingat, bahwa Nabi Muhammad SAW sebagai pemimpin agama dan negara di Madinah pada masa itu tidak pernah melakukan pemaksaan dan kekerasan terhadap pemeluk agama non-Islam (Pulungan, 1994: 32). Jika dibayangkan, alangkah indahnya jika semua umat beragama saling bahumembahu untuk membagun bangsa dan negara ini, tanpa ada saling curiga satu sama lain. Secara teologis memang antara satu agama dengan agama yang lain berbeda, namun tidak ada alasan dengan perbedaan 
itu lalu kita tidak mampu hidup bersama, sebab ada nilai kemanusiaan universal yang mesti ditegakkan oleh setiap umat beragama, misalnya, menegakkan keadilan, kejujuran kasih-sayang sesama dan seterusnya.

Hidup berbangsa dan bernegara dalam pluralitas keberagamaan ini ibarat kita berada di tengah-tengah pasar tradisional. Dalam pasar ini berbagai macam dagangan dipasarkan oleh berbagai penjual yang beragam agama dan aliran kepercayaannya. Hampir-hampir tidak pernah ada konflik karena dagangannya itu. Dan pembeli tidak pernah berpikir siapa yang menjual dagangan itu, apakah Muslim, Krsiten atau apa saja (kecuali terkait dengan kehalalan atau keharaman barang tersebut). Bahkan justru kita lebih senang membeli barang kepada penjual yang dapat memuaskan kita (costumer focus), plus lengkap dagangannya. Di sini setiap penjual dituntut untuk memberikan pelayanan yang terbaik kepada pelanggan atau pembeli, dan dituntut pula menyediakan barang dagangan yang lengkap dan terjamin kualitasnya. Ibarat pasar tersebut, orang beragama dituntut dapat melayani umat dengan sebaik-baiknya, menawarkan misi agamanya secara menarik dan menawan hati umat (fastabiq al khairat). Kita tidak perlu terjebak oleh seberapa besar kuantitas yang menjadi pengikut kita. Sebab ini tidak menjadi tuntutan agama, yang dituntut kepada kita adalah, seberapa besar keseriusan dan ketulusan kita dalam berdakwah, mengemban misi agama itu sendiri, soal mereka bersedia menjadi pengikut atau tidak itu adalah urusan Tuhan. Namun, kita yakin, bahwa mereka akan memilih menjadi pengikut bagi penyeru agama yang serius menegakkan keadilan, kasih-sayang dan kemanusiaan universal.

\section{Simpulan}

Kebebasan beragama dalam konteks Indonesia diatur dalam undang-undang sebagai "bebas untuk memilih dan memeluk agama tertentu", bukan bebas untuk tidak beragama, karena Indonesia adalah negara Pancasila yang berdasarkan pada Ketuhanan Yang Maha Esa. 
Dalam perspektif sosial, pluralisme menangkal dominasi dan hegemoni kelompok atau aliran keagamaan, serta menegasikan pemusatan kekuatan sosial pada satu kelompok atau aliran. Sedangkan perspektif pluralisme budaya mencegah hilangnya satu aliran karena dilenyapkan oleh aliran keagamaan arus utama yang hegemonis, dan di sisi lain menangkal arogansi aliran keagamaan arus utama yang seringkali tergoda atau secara historis-empiris melakukan pelecehan dan penindasan aliran atau agama lain. Sementara pluralisme politik dapat menjadi dasar bagi jaminan kebebasan untuk berkeyakinan dan berekspresi tanpa rasa takut akan ancaman kekerasan, karena adanya lembaga pengelola konflik kepentingan antaraliran keagamaan.

Secara empirik, kebebasan beragama di Indonesia belum berjalan dengan baik, terbukti masih ada agama yang dilarang karena dianggap "sesat". Masih terjadi tindak kekerasan oleh satu agama ataui aliran terhadap agama atau aliran yang lain. Kasus pelarangan terhadap aliran agama yang dianggap sesat, seperti Ahmadiyah dan aliran keagamaan yang lain oleh pemerintah menunjukkan hal ini, demikian pula sekelompok umat yang melakukan tindak kekerasan dan perusakan tempat-tempat ibadah terhadap agama atau aliran lain juga merupakan bukti empirik akan adanya pelanggaran HAM tersebut.

\section{Daftar Pustaka}

Billah. M.M. 2007. Pluralitas Agama di Indonesia: Memilih Kerangka Pemahaman atas Keberadaan Aliran Keagamaan dari Perspektif Teologi dan HAM. Malang: UIN Malang.

Haryatmoko. 1999. Pluralisme Agama dalam Perspektif Filsafat. Yogyakarta: IAIN Sunan Kalijaga.

Mulia, Musdah. 2005. Hak Asasi Manusia dan Kebebasan Beragama. berita/html. [06 Mei 2005]. www.sinarharapan.co.id/berita/ opi01.html

Pulungan, J. Suyuthi. 1994. Prinsip-prinsip Pemerintahan dalam Piagam 
Madinah Ditinjau dari Pandangan al Quran. Jakarta: Rajawali Press. Reese. 1999. Dictionary of Philosophy and Religion. New York: Humanities Books.

Solomon, Robert C dan Katheleen M. Higgins. 2002. Sari Sejarah Filsafat. Terjemahan oleh Saut Pasaribu. Yogyakarta: Yayasan Benteng Budaya

www. islamlib.com. Artikel kebebasan beragama dan berkeyakinan. [18 Maret 2005]. 